The Impact of Public Perception of Earthquake Risk on Istanbul's Housing Market

Author(s): Zeynep Önder, Vedia Dökmeci and Berna Keskin

Source: Journal of Real Estate Literature, Vol. 12, No. 2 (2004), pp. 181-194

Published by: American Real Estate Society

Stable URL: https://www.jstor.org/stable/44103487

Accessed: 29-12-2018 16:58 UTC

JSTOR is a not-for-profit service that helps scholars, researchers, and students discover, use, and build upon a wide range of content in a trusted digital archive. We use information technology and tools to increase productivity and facilitate new forms of scholarship. For more information about JSTOR, please contact support@jstor.org.

Your use of the JSTOR archive indicates your acceptance of the Terms \& Conditions of Use, available at https://about.jstor.org/terms

American Real Estate Society is collaborating with JSTOR to digitize, preserve and extend access to Journal of Real Estate Literature 


\title{
The Impact of Public Perception of Earthquake Risk on Istanbul's Housing Market
}

\author{
Zeynep Önder,* Vedia Dökmeci** and Berna Keskin***
}

\begin{abstract}
This paper examines the impact of public perception of earthquake risk on Istanbul's housing market by investigating the spatial distribution of the average house values and the changes in average house prices in Istanbul between 1995 and 2000. Soil type and distance to the fault lines in the Sea of Marmara are used as proxies for public perception of earthquake risk. The results of regression analysis show that distance from fault lines is an important factor in explaining house values and its impact on house values increased after the 1999 Kocaeli earthquake. Furthermore, there is a quadratic relationship between soil type and house values. However, none of the measures of earthquake risk significantly affect the change in house values. These findings suggest that public perception of earthquake risk enhanced and the public information about earthquake hazard had significant impact on house values.
\end{abstract}

\section{Introduction}

The purpose of this paper is to examine the impact of the public perception of earthquake risk on house prices in Istanbul between 1995 and 2000. The introduction of natural hazards information into a market will potentially alter individuals' perception of risk as that risk relates to investment activities (Bernknopf, Brookshire and Thayer, 1990). After the Kocaeli earthquake in 1999, the public became more conscious of dangers of a catastrophic earthquake such as injury and death, damage to property and disaster relief costs. Public perception of earthquake risk has been developed by continual media attention to warnings from geologists about soil types and the distance from the fault lines in the Sea of Marmara. It is known that certain types of soil enhance ground motion and increase earthquake damage. Also, fault lines are described with a probability distribution of possible earthquake magnitudes. It is expected that these warnings have caused temporary shocks to the market and the community proportional to the level of the risk announced. In fact, although a probabilistic seismic hazard map has not been yet prepared, demand for housing in a few neighborhoods has increased and thus housing prices have too, while in others, it has fallen according to public perceptions of geologists' findings.

Although there have been several studies to determine environmental impacts on housing prices, the few studies with respect to earthquake risks have been mostly in

*Bilkent University, Ankara, Turkey or zonder@bilkent.edu.tr

**Istanbul Technical University, Taksim, Istanbul, Turkey or dokmeciv@itu.edu.tr.

***Istanbul Technical University, Turkey or berna.keskin2@itu.edu.tr. 
the United States (Willis and Asgary, 1997). Those studies use different methods to determine the effect of earthquake risks on the housing market, and have produced somewhat different results. Brookshire and Schulze (1980) developed a contingent valuation method to determine the effects of earthquake risk on the housing market in California. According to their results, only $26 \%$ of respondents were willing to pay more for a stronger construction. Palm $(1987,1990)$ did a group of studies on housing markets and earthquake risks. She investigated the effectiveness of mandated disclosure legislation in California. According to this legislation, real estate agents should inform all home buyers about the seismic risk related to the location of a house. Her study showed that people paid little attention to earthquake hazards. Palm (1990) also conducted a survey of real estate appraisers to evaluate their methods of dealing with earthquake hazards. The results of her study showed that the legislation did not significantly affect the housing market. Most of the appraisers did not give any higher price on an identical property in a lower risk area. They indicated that clients had only rarely asked about seismic hazards, and few purchasers checked for evidence of previous damage from earthquakes or location on a surface-fault trace (Willis and Asgary (1997). Bernknopf, Brookshire and Thayer (1990) studied the effects of earthquake hazard risks on investment behavior and housing prices in the resort community of Mammoth Lakes in California. According to their results, the hazard notices affected investment, but not recreational use. However, a perceived loss in the market value of homes was documented. Another study by Murdoch, Singh and Thayer (1993) showed the effect of the Loma Prieta earthquake on the housing prices. They observed a $2 \%$ reduction in house prices. Studies by Brookshire, Thayer, Tschirhat and Schultze (1985) and MacDonald, Murdoch and White (1987) illustrated that risk information had an influence on the housing markets. A comprehensive review of the previous research by Willis and Asgary (1997) reveals that an earthquake can influence the short-term housing market. Also, they illustrate a lack of information on the effects of earthquake risk on housing markets in developing countries.

Although there are some studies on the impact of earthquake risk on housing values in developed countries, there is only one excellent study by Willis and Asgary (1997) in developing countries, where earthquake hazards are often more catastrophic than in developed countries due to their substandard housing and less efficient disaster management programs (Tuker, Trumbull and Wyss (1994). Using a contingent valuation method, a survey of real estate agents was conducted by Willis and Asgary to find the effects of earthquake risk reduction measures on the housing market in Tehran, Iran, which is located in a high-earthquake-risk zone. The results showed that there was a significant price difference between earthquake-resistant houses across all districts in the city. This difference might further increase with the increased information about earthquake risk. The authors measured the impacts of construction policies rather than land use policy regulations, holding location constant. In contrast to previous research, this current study estimates real difference among houses in terms of resistance to earthquakes of different magnitudes.

This paper investigates the relationships between housing unit prices and earthquake risk measured by soil types and distance from the fault lines in the Sea of Marmara in Istanbul, Turkey. The organization of the paper is as follows. Background

VOLUME 12, NUMBER 2, 2004 
information about the general structural characteristics of Istanbul and the changes of house prices in recent years is presented, followed by a discussion of a regression analysis of changes in residential prices with respect to soil types and distances from the fault lines in the Sea of Marmara. Finally, concluding comments are presented.

\section{Background}

Istanbul, with a population of 10 million, is the largest city in Turkey. Major qualitative differences exist in the economic, social and environmental conditions that characterize Istanbul. It is the most important financial, cultural and educational area of the country. At the same time, it is a city world-famous for its natural beauty and historical monuments, reflecting its role as the capital of three separate empires. It enjoys shorelines on the Black Sea, the Sea of Marmara and the Bosphorus Strait, which attract people throughout the country and the demand for and thus the price of housing increase in Istanbul. Moreover, the rapid growth of the city since the 1950s, due to rural migration, has affected the quality of life in various sections of the city. While some of the modern districts have become comparatively more attractive, the historic districts have lost wealthy population due to the deterioration of their neighborhoods and the settlement of low income migrants. Meanwhile, alternating periods of rampant inflation have spurred the demand for real estate, one of the few inflation-resistant forms of investment-just as it is in many countries, developed as well as developing. Furthermore, the construction of bridges on the Bosphorus and the Golden Horn have changed the accessibility of various areas measurably, and have thus caused a transformation in the land-use pattern from mono-centric to multi-centric development. Moreover, the construction of the modern housing projects on the periphery has created not only new opportunities for housing markets but also a trend toward living in modern urban settlements surrounded by green areas with suburban amenities. Since officially sanctioned housing, services and infrastructure have not kept pace with the rapid population increase, unauthorized settlements on the periphery have resulted. These changes have created locational advantages or disadvantages, which are reflected in the real estate market and intra-urban migration, which in turn have affected demand for housing and housing prices (Dokmeci et al. 1996; and Dokmeci and Berkoz, 2000).

Istanbul's urban neighborhoods have considerably differed economically and culturally from one another throughout history. These differences have come not only from being the capital of three empires but also from its multi-cultural structure and international characteristics. Moreover, there is substantial evidence that these differences have become greater in recent years.

The transformation of Istanbul from a mono-centric into a multi-centric city produced three peak housing price areas (Dokmeci and Berkoz (1994). One of these, located between the new Central Business District (CBD) (Sisli-Mecidiyekoy) and the Bosphorus, has the highest residential prices. This area has the greatest accessibility to both high-paid jobs and scenic views of the Bosphorus; it also has equal accessibility to different parts of the city via the peripheral highways. This development axis has two prestigious universities and a large shopping mall $\left(250,000 \mathrm{~m}^{2}\right){ }^{1}$ 
As a result, the area attracts middle- and upper-income people, producing a prestigious area with high residential prices.

Bakirkoy, the district with the second highest residential prices in its neighborhoods such as Yesilkoy, Yesilyurt and Florya, is located on the Sea of Marmara, near the airport, a large shopping mall and a marina with luxurious hotel and office complexes. This is a traditional high-status suburban area with easy access to peripheral highways and to the CBD. It also enjoys seashore amenities. Moreover, housing demand from high-paid airline personnel who prefer to live close to the airport increases residential prices in this area.

The district with the third highest residential prices is Kadikoy located on the Asian side of Istanbul. This area with its modern housing and exclusive pedestrian shopping street (10 km long), enjoys amenities from being on the cost. This is a traditional high-status area continuously attracting many well-to-do families from other districts (Dokmeci et al., 1996).

\section{Data and Empirical Model}

The impact of public perception of earthquake risk on housing values is investigated for the homogeneous neighborhoods of Istanbul for the years 1995 and 2000. In the analysis, homogeneous neighborhoods are used as a unit of observation instead of districts because neighborhoods located in the same district might show different characteristics. For example, Atakoy and Bakirkoy are located in Bakirkoy district and although the average size of the houses in these neighborhoods was similar in 2000 , the average house value per square meter was $\$ 1,209$ (819 million TL) and $\$ 431$ (292 million TL) in these neighborhoods respectively (see the Appendix). A homogeneous neighborhood is defined as a spatially contiguous region of the city with sufficient population to be considered as a neighborhood in which all resident households and housing units have similar characteristics. These characteristics include an entire array of housing stock/service and site characteristics, resident household characteristics, neighborhood amenities and accessibility characteristics rather than just the usual income characteristics. Factors operating on the demand or supply side of the market (or both), create tendencies for spatial concentration of liketype households, house units, neighborhood amenities or accessibility. Differences in demand or supply conditions can arise from the following sources: different preferences of households, different incomes and wealth among households, and different cost functions of housing suppliers. These differences in turn can result in a differentiated price structure across neighborhoods and hence differentiated locational choice (Vandell, 1995).

House values are obtained from the advertisements in the newspapers for the month of October in 1995 and 2000 . This month was especially chosen since there are usually a lot of housing transactions. There were 5,627 and 1,525 cases gathered about price, size and location of houses from the advertisements in 1995 and 2000 respectively. Average house price and average house size for each neighborhood is calculated from these data. Since the average size of housing units show variation among 
neighborhoods, the house value per square meter is used in the estimations. These values are reported in the Appendix and shown in Exhibit 1.

Twenty-eight neighborhoods on the Asian side of the city and 35 neighborhoods from the European side are taken into consideration. The mean values were higher on the European side than the Asian side in both years. However, the average house size was larger on the Asian side. There were some variations in values among neighborhoods (Exhibit 2). For example, the mean house value per square meter was 39 million Turkish Liras (TL) (\$730) in 1995, changing between $\$ 151$ in Gaziosmanpasa and \$2,692 in Bebek. The average house values per square meter increased in 2000 to $\$ 875$. The lowest value, $\$ 195$, was observed in Avcilar, which is considered to be affected most from the earthquake. Even in 2000, Bebek had the most expensive houses with the average value of $\$ 3,958$ per square meter.

In the analysis of the change in house values over time with the earthquake, it is assumed that prices in all neighborhoods increase at a rate equal to the increase in the cost of construction index $(\mathrm{CCI})^{2}$ since there are more years before the earthquake than after. Hence, the 1995 values are deflated at the cost of construction. These deflated values show the average house value in 2000 if house prices increased at a rate equal to the increases in CCI since 1995. Then, the percentage change between the actual 2000 averages and the deflated 1995 values is used in order to examine the impact of earthquake risk on the change in house values. ${ }^{3}$

While average unit house price increased $38 \%$ in all neighborhoods, there are some variations on the change in house prices in both sides of the city. The range of house price changes varies on the Asian side from -24\% in Goztepe to $287 \%$ in Cengelkoy because Goztepe is nearer to the fault line than Cengelkoy, which also enjoys the amenities of the Bosphorus. There was only a $32 \%$ increase on the Usküdar Coast, which enjoys the most beautiful view of the Topkapi Palace, and $70 \%$ increase in Atasehir, which is a relatively new neighborhood constructed with advanced techniques by well-known construction companies, wining the Habitat II reward in 1996. It is also far from the fault line. In contrast, there was an $11 \%$ decrease in a historical neighborhood (Moda), which is also nearer the fault line. On the other hand, in the European side of the city, the range of house price change varies from a $230 \%$ increase in Macka, which is claimed by geologists to have very sound soil to a $42 \%$ decrease in Ok Meydani. The reasons can be the lack of infrastructure and investment in Ok Meydani while Macka has a more resistant soil type. Moreover, a 9\% increase is observed in Mecidiyekoy, which is in the new CBD. Meanwhile, it is known that a 12\% decrease in the average unit house prices in Yesilkoy and Yesilyurt and a 16\% decline in Avcilar are due to low quality soil and short distance to the fault line located in the Sea of Marmara. As a very heterogeneous total, the average house price per square meter increased $28.2 \%$ on the Asian side and $45.9 \%$ on the European side of the city.

Although Istanbul has had some major earthquakes during its history, none of them have been destructive enough to destroy major 500 or 1500 years old historical buildings according to some international geologists such as McKenzie. Therefore, if 


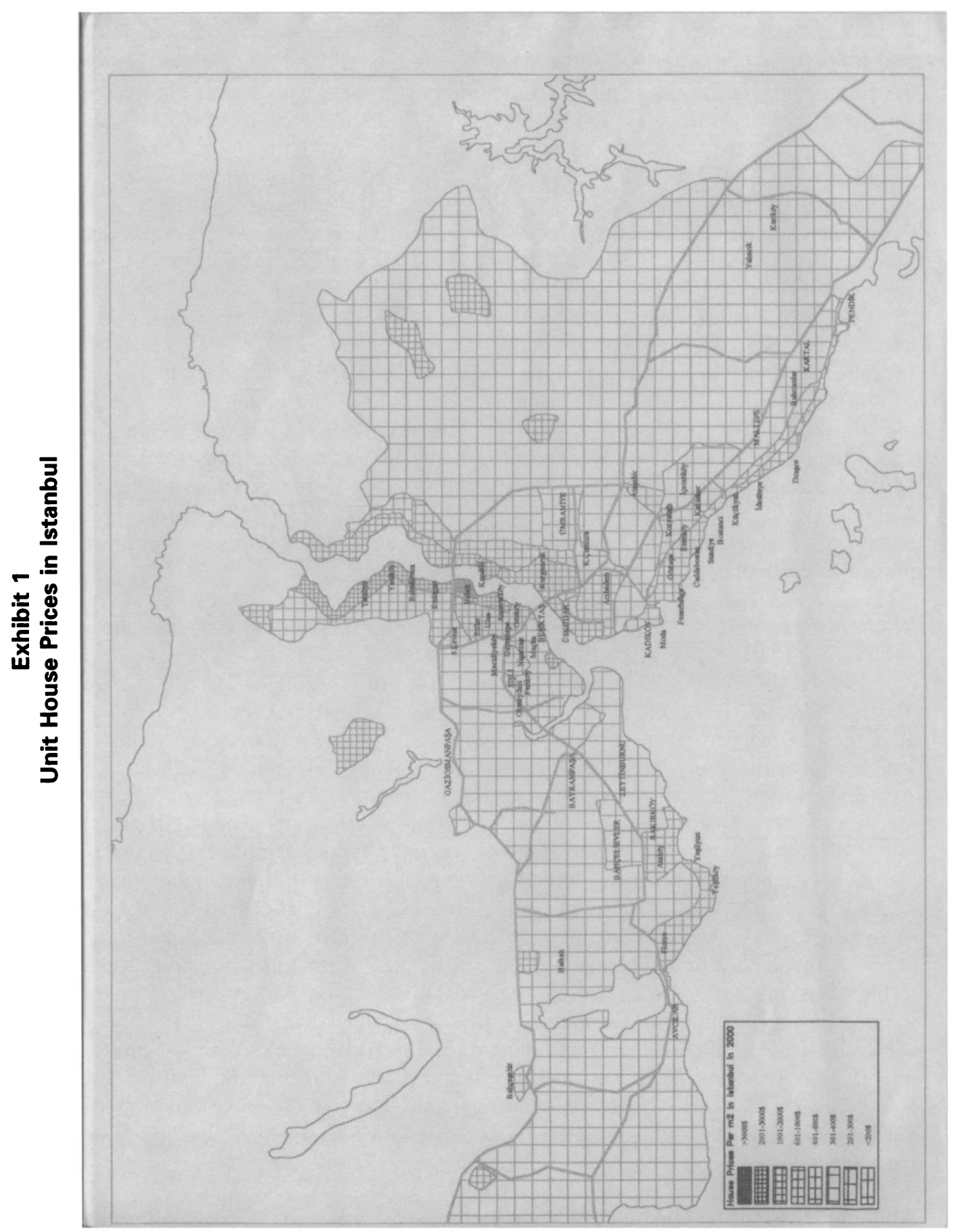

VOLUME 12, NUMBER 2, 2004 


\section{Exhibit 2}

Descriptive Statistics of Variables

\begin{tabular}{|c|c|c|c|c|}
\hline Variable & Mean & Std. Dev. & Min. & Max. \\
\hline \multicolumn{5}{|l|}{ Housing Characteristics } \\
\hline $\begin{array}{l}\text { House Values (in million TL) } \\
1995 \\
2000\end{array}$ & $\begin{array}{r}6,266 \\
134,052\end{array}$ & $\begin{array}{r}5,607 \\
171,185\end{array}$ & $\begin{array}{r}680 \\
14,356\end{array}$ & $\begin{array}{r}25,861 \\
776,866\end{array}$ \\
\hline $\begin{array}{l}\text { Per square meter (in million TL) } \\
1995 \\
2000\end{array}$ & $\begin{array}{r}39 \\
596\end{array}$ & $\begin{array}{r}28 \\
521\end{array}$ & $\begin{array}{r}8 \\
133\end{array}$ & $\begin{array}{r}135 \\
2,694\end{array}$ \\
\hline $\begin{array}{l}\text { House Values (in \$US) } \\
1995 \\
2000\end{array}$ & $\begin{array}{l}125,208 \\
196,897\end{array}$ & $\begin{array}{l}112,033 \\
251,951\end{array}$ & $\begin{array}{l}13,587 \\
21,121\end{array}$ & $\begin{array}{r}516,729 \\
1,146,875\end{array}$ \\
\hline $\begin{array}{l}\text { Per square meter (in \$US) } \\
1995 \\
2000\end{array}$ & $\begin{array}{l}783 \\
875\end{array}$ & $\begin{array}{l}564 \\
766\end{array}$ & $\begin{array}{l}151 \\
195\end{array}$ & $\begin{array}{l}2,692 \\
3,958\end{array}$ \\
\hline $\begin{array}{l}\text { Growth rate of House Values pe } \\
\text { Deflated with } \mathrm{CCl} \\
\text { in \$US }\end{array}$ & $\begin{array}{r}\text { Iare meter }(\% \\
38.19 \\
14.18\end{array}$ & $\begin{array}{l}63.41 \\
52.19\end{array}$ & $\begin{array}{l}-42.31 \\
-52.69\end{array}$ & $\begin{array}{l}287.46 \\
218.41\end{array}$ \\
\hline $\begin{array}{l}\text { Size of Housing Units (square } n \\
1995 \\
2000\end{array}$ & $\begin{array}{l}138.76 \\
176.53\end{array}$ & $\begin{array}{l}31.97 \\
75.88\end{array}$ & $\begin{array}{l}64.33 \\
71.92\end{array}$ & $\begin{array}{l}235.00 \\
430.00\end{array}$ \\
\hline $\begin{array}{l}\text { Earthquake Risk Measures } \\
\text { Soil Type } \\
\text { Distance from Fault Lines }\end{array}$ & $\begin{array}{l}12.09 \\
16.09\end{array}$ & $\begin{array}{l}3.75 \\
6.05\end{array}$ & $\begin{array}{l}3.00 \\
5.10\end{array}$ & $\begin{array}{l}16.00 \\
31.70\end{array}$ \\
\hline $\begin{array}{l}\text { Other Neighborhood Characteri } \\
\text { Age } \\
\text { Asia } \\
\text { Distance from CBD } \\
\text { Commercial (Dummy Variable) }\end{array}$ & $\begin{array}{r}11.80 \\
0.44 \\
15.48 \\
0.86\end{array}$ & $\begin{array}{l}8.18 \\
0.50 \\
9.64 \\
0.35\end{array}$ & $\begin{array}{l}0.00 \\
0.00 \\
4.00 \\
0.00\end{array}$ & $\begin{array}{r}35.00 \\
1.00 \\
39.00 \\
1.00\end{array}$ \\
\hline
\end{tabular}

Note: $N=64$.

there is one in the future, it will probably not be any more destructive. However, it is worthwhile to investigate seismic impact by looking at housing prices and their changes in certain neighborhoods, and the recommendations of geologists.

In this study, earthquake risk is proxied by two variables: the soil type of the neighborhood and the distance from the fault lines located in the Sea of Marmara. The distance from the fault lines is calculated using the map prepared by the Istanbul Metropolitan Municipality. Although people generally know the type of soil where their houses are located, the distance from the fault lines became public information after the 1999 Kocaeli earthquake with the expectation of another major earthquake in the region in the next forty years. The distance from the fault lines varies from 5.10 kilometers (Yesilyurt and Yesilkoy) to 31.70 kilometers (Maslak). Soil type is graded from 1 to 16 according to geological data dealing with earthquake risk (16 being the safest, and one being the least). Soil type is also obtained from the city 
government. Exhibit 3 depicts the fault lines and soil types of different neighborhoods in Istanbul. The lowest quality soil is observed in Avcilar; the soil in Cengelkoy is one of the safest, and the area had the highest increase in unit house values in 2000. The other safest neighborhoods in terms of soil type are Dragos, Pendik and Kandilli.

The relationship between the unit house prices and earthquake risk measured by soil types and earthquake risk is investigated by regression analysis. While some studies have used hedonic price method to analyze the impact of earthquake risk on house prices in developed countries (Brookshire et al., 1985; and Bernknopf, Brookshire and Thayer 1990), the application of hedonic price method in many developing countries is difficult because of a lack of sufficient data (Willis and Asgary, 1997). In fact, there is no database of house price transactions in Istanbul that can be used to determine the relationships between house characteristics, socioeconomic neighborhood effects, location, accessibility to facilities and earthquake risk and house prices. Hence, house values in homogeneous neighborhoods are estimated by controlling very few neighborhood characteristics.

In order to examine how house values were affected after the major earthquake, Model 1 is estimated for the 1995 and 2000 separately at the neighborhood level:

\section{Exhibit 3}

\section{Soil Types and Fault Lines in Istanbul}

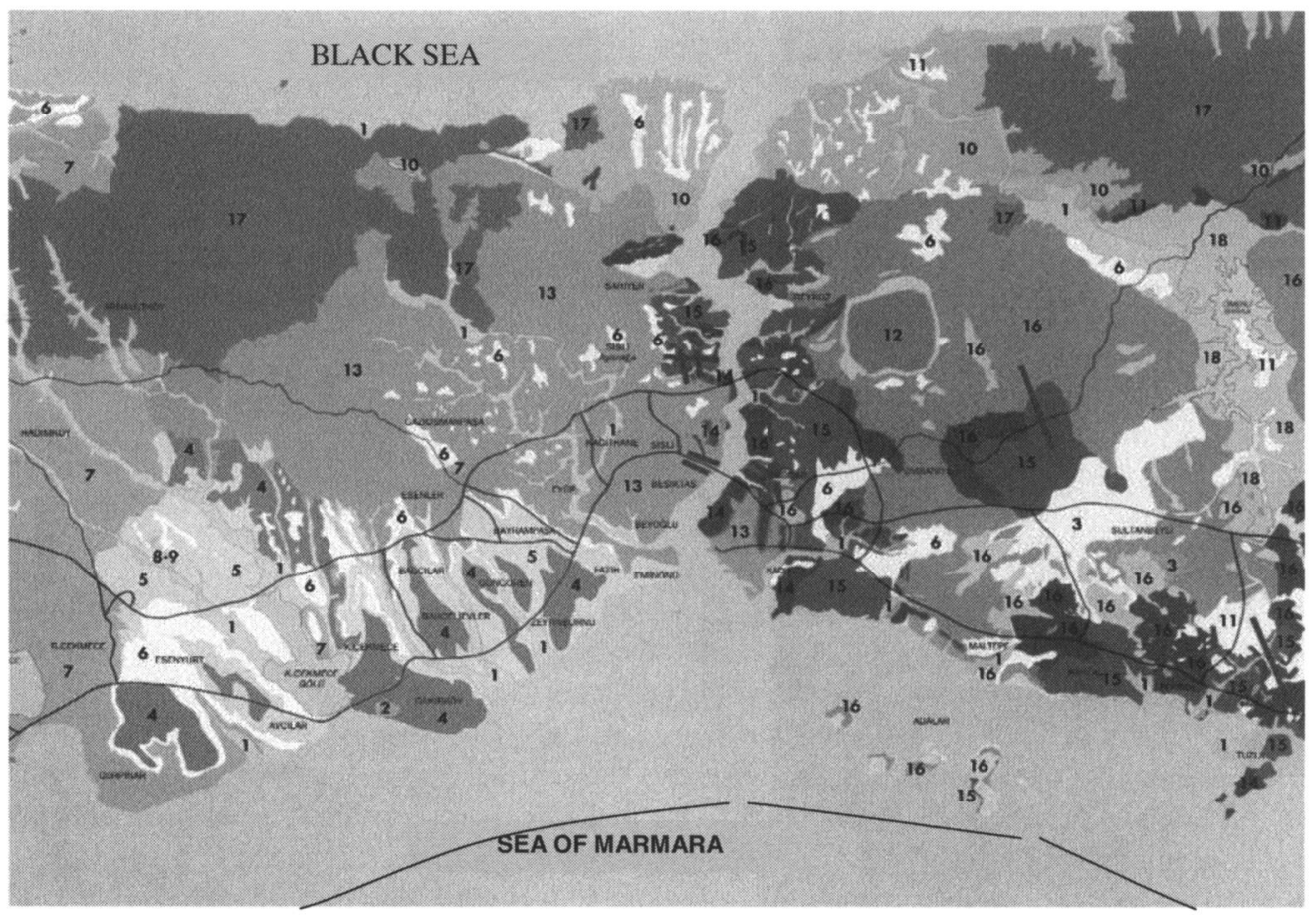

VOLUME 12, NUMBER 2, 2004 


$$
\begin{aligned}
\text { Value }_{i}= & \beta_{0}+\beta_{1} \text { Distance }_{i}+\beta_{2} \text { Soil }_{i}+\beta_{3} \text { Asia }_{i}+\beta_{4} \text { Age }_{i} \\
& +\beta_{5} \text { DistanceCBD }_{i}+\varepsilon_{i},
\end{aligned}
$$

where Value $_{i}$ is the logarithm of the average house value per square meter in neighborhood $i$ in years 1995 and 2000. Distance $_{i}$ represents the distance of the neighborhood to the fault lines expressed in kilometers. Soil ${ }_{i}$ shows the type of soil and it is an ordinal number taking a value between 3 and 16. As this variable increases, the quality of soil for constructions increases. The impact of these variables on the house values is expected to increase in 2000, after the major earthquake. Asia ${ }_{i}, A_{g} e_{i}$ and Distance $C B D_{i}$ are control variables that affect house values in neighborhoods. $A g e_{i}$ is the average age of houses in each neighborhood, obtained from Egdemir (2001). As the average age of housing units in neighborhood increases, it is expected that the value of houses will decline since the old building construction is less earthquake resistant. DistanceCBD ${ }_{i}$ represents the distance to the major CBD in Istanbul, Besiktas. Accessibility to the CBD may be considered as a positive amenity and those neighborhoods that are closer to the CBD are expected to have higher house values. Since most of the residents live in the Asian side of the city and work in the European, a dummy variable, Asia $_{i}$, is included to control for this effect on house values. As reported in Exhibit 2, 44\% of neighborhoods are located in the Asian side of the city. The average age of housing units was 11.80 years. The distance to the CBD changes between 4 and 39 kilometers.

The effect of earthquake risk on the change in house values is estimated using Model 2:

$$
\begin{aligned}
\text { ChangeinValue }_{i}= & \beta_{0}+\beta_{1} \text { Distance }_{i}+\beta_{2} \text { Soil }_{i}+\beta_{3} \text { Asia }_{i}+\beta_{4} \text { Age }_{i} \\
& +\beta_{5} \text { DistanceCBD }_{i}+\varepsilon_{i},
\end{aligned}
$$

where ChangeinValue ${ }_{i}$ represents the percentage change in unit house value from deflated 1995 prices and the 2000 prices.

\section{Empirical Results}

It is expected that there will be a higher impact of earthquake risk measures on house values after the 1999 earthquake, assuming that consumers have enough information on earthquake risks where they live. Exhibits 4 and 5 present the results of the regression analysis for years 1995 and 2000. It is found that as distance from the fault lines increases, the value of houses increases. Furthermore, as expected, the impact of this earthquake risk measure increases after the earthquake. However, no evidence of significant impact of soil type on house values was found. However, it is possible that there is non-linear relationship between soil type and house value. ${ }^{4}$ Another model that includes square of soil type is also estimated in order to find out any non-linear relationship. These findings indicate that house values decline at low levels of soil type and as the quality of soil increases, house values increase significantly controlling 
Exhibit 4

Regression Analysis of House Values per Square Meter in 1995 and 2000

\begin{tabular}{|c|c|c|c|c|}
\hline & \multicolumn{2}{|l|}{ Model I } & \multicolumn{2}{|l|}{ Model II } \\
\hline & 1995 & 2000 & 1995 & 2000 \\
\hline Intercept & $\begin{array}{l}16.153^{* * *} \\
(37.70)\end{array}$ & $\begin{array}{l}18.830^{* * *} \\
(44.81)\end{array}$ & $\begin{array}{l}17.689 * * * \\
(24.42)\end{array}$ & $\begin{array}{l}20.512^{* * * *} \\
(29.28)\end{array}$ \\
\hline $\begin{array}{l}\text { Measures of Earthquake R } \\
\text { Soil Type }\end{array}$ & $\begin{array}{l}-0.006 \\
(-0.20)\end{array}$ & $\begin{array}{l}-0.005 \\
(-0.17)\end{array}$ & $\begin{array}{l}-0.375^{* *} \\
(-2.56)\end{array}$ & $\begin{array}{l}-0.409 * * * \\
(-2.89)\end{array}$ \\
\hline Soil Type ${ }^{2}$ & & & $\begin{array}{l}0.019^{* *} \\
(2.57)\end{array}$ & $\begin{array}{l}0.021 * * * \\
(2.91)\end{array}$ \\
\hline Distance from Fault Lines & $\begin{array}{l}0.049 * * \\
(2.63)\end{array}$ & $\begin{array}{l}0.070^{* * * *} \\
(3.80)\end{array}$ & $\begin{array}{l}0.052^{* * *} \\
(2.89)\end{array}$ & $\begin{array}{l}0.073^{* *} \\
(4.18)\end{array}$ \\
\hline \multicolumn{5}{|c|}{ Other Neighborhood Characteristics } \\
\hline Age & $\begin{array}{l}0.021^{*} \\
(1.80)\end{array}$ & $\begin{array}{r}0.010 \\
(0.83)\end{array}$ & $\begin{array}{l}0.020^{*} \\
(1.75)\end{array}$ & $\begin{array}{c}0.008 \\
(0.73)\end{array}$ \\
\hline Asia & $\begin{array}{c}-0.167 \\
(-0.49)\end{array}$ & $\begin{array}{r}0.087 \\
(0.26)\end{array}$ & $\begin{array}{l}-0.025 \\
(-0.07)\end{array}$ & $\begin{array}{c}0.243 \\
(0.75)\end{array}$ \\
\hline Distance from CBD & $\begin{array}{c}0.013 \\
(0.69)\end{array}$ & $\begin{array}{l}-0.008 \\
(-0.46)\end{array}$ & $\begin{array}{c}0.002 \\
(0.10)\end{array}$ & $\begin{array}{c}-0.021 \\
(-1.16)\end{array}$ \\
\hline Adjusted $R^{2}$ & 0.1512 & 0.3178 & 0.2259 & 0.3955 \\
\hline F-Statistic & 3.24 & 6.87 & 4.06 & 7.87 \\
\hline$p$-value & 0.0119 & $<0.0001$ & 0.0018 & $<0.0001$ \\
\hline Durbin-Watson statistic & 2.028 & 1.955 & 1.991 & 2.073 \\
\hline
\end{tabular}

Notes: $t$-Statistics are presented in parentheses. $N=64$.

* Significant at the $10 \%$ level.

** Significant at the $5 \%$ level.

*** Significant at the $1 \%$ level.

Exhibit 5

Test of Equality of Measures of Earthquake Risk in 1995 and 2000

\begin{tabular}{lllll}
\hline & F-Statistic & $p$-value & F-Statistic & $p$-value \\
\hline Soil Type & 0.00 & 0.9506 & 0.15 & 0.7026 \\
Soil Type & & & 0.16 & 0.6877 \\
Distance from Fault Lines & 3.69 & 0.0597 & 3.71 & 0.0592 \\
\hline
\end{tabular}

Notes:

* Significant at the $10 \%$ level.

** Significant at the $5 \%$ level.

***Significant at the $1 \%$ level.

VOLUME 12, NUMBER 2, 2004 
for the distance from the fault lines and age of housing units, distance from CBD and location of the neighborhood. Moreover, explanatory power of the model is higher for the year 2000 than for 1995. Even in the second model, the impact of distance from fault lines on house values increases significantly in 2000 because people became more conscious after earthquake.

Exhibit 6 reposts the results of the regression analysis of the changes in house values. The measures of earthquake risk seem to explain $9.28 \%$ of the variation in the percentage change in house values. However, although distance from fault lines is a significant factor affecting the growth in house values, its effect disappears when other neighborhood characteristics are controlled for. None of the earthquake risk measures significantly affects the change in house values before and after the earthquake.

\section{Conclusion}

This study investigates the relationship between the changes in average unit house prices between 1995 and 2000 and soil types and distances from the fault lines in Istanbul. Regression analysis is used for the investigation. After the Kocaeli earthquake in 1999, people became more conscious of earthquake risk. Geologists' warnings have heightened public awareness and promoted hazard mitigation in case

\section{Exhibit 6}

Change in House Values: 1995-2000

\begin{tabular}{lccc}
\hline & Restricted Models & & Full Model \\
\hline Intercept & -0.214 & $1.177^{* * *}$ & 0.637 \\
Measures of Earthquake Risk & $(-0.80)$ & $(4.50)$ & $(1.45)$ \\
Soil Type & -0.004 & & -0.001 \\
& $(-0.17)$ & & $(-0.04)$ \\
Distance from Fault Line & 0.037 & & 0.023 \\
& $(2.50)$ & & $(1.24)$ \\
Neighborhood Characteristics & & $-0.025^{* *}$ & $-0.022^{* *}$ \\
Age & & $(-2.39)$ & $(-2.03)$ \\
& & $0.800^{* *}$ & 0.669 \\
Asia & & $(2.64)$ & $(2.03)$ \\
& & $-0.059^{* * *}$ & -0.045 \\
Distance from CBD & & $(-3.42)$ & $(-2.35)$ \\
& & 0.1417 & 0.1481 \\
Adjusted $R^{2}$ & 0.0928 & 4.19 & 3.02 \\
F-Statistic & 3.97 & 0.0096 & 0.0181 \\
p-value & 0.0245 & 2.004 & 2.0400 \\
Durbin-Watson statistic & 1.9300 & $\beta_{\text {Sistance from fault lines }}=0$. & \\
\hline Notes: $N=57$. Test of Hypothesis & & \\
F-test $=0.1091$, which is not significant. & & & \\
\hline
\end{tabular}


of an earthquake. Although there are many factors that affect housing prices in Istanbul due to its rapid growth and thus dynamic structure, none of the earthquake risk measures significantly affects the change in house values before and after the Kocaeli earthquake. So, the impact of geologists' warnings about soil types was limited to only a few high-income locations, thus not thus influencing the regression results. Since municipal governments of districts have required local soil inspection reports for construction permits, this measure will help to obtain more scientific information about soil types and thus a more realist evaluation of their impact on housing prices in the future.

Previous studies suggest that an earthquake can influence the housing market in the shorter term (Willis and Asgary, 1997). Also in Istanbul, in 2000, one year after the Kocaeli earthquake 1999, the amount of people who desire to investigate their buildings' construction systems with respect to earthquake resistance was nil. Therefore, market activity seems to have returned to pre-warning levels once the announcements stopped and the perceived risk to individuals subsided (Bernknopf, Brookshire and Thayer, 1990). This research can be extended to include a hedonic price method and other metropolitan areas in Turkey in order to drive more general results.

\section{Appendix}

Characteristics of Housing Units in Neighborhoods: 1995 and 2000

\begin{tabular}{|c|c|c|c|c|c|c|}
\hline \multirow[b]{2}{*}{ Neighborhood } & \multicolumn{3}{|c|}{1995 Deflated at $\mathrm{CCl}$} & \multicolumn{3}{|l|}{2000} \\
\hline & Mean & $\begin{array}{l}\text { Std. Dev. } \\
\text { of Value }\end{array}$ & Size & Mean & $\begin{array}{l}\text { Std. Dev. } \\
\text { of Value }\end{array}$ & Size \\
\hline \multicolumn{7}{|c|}{ Panel A: Neighborhoods in the European Side } \\
\hline Akatlar & 543 & 223 & 121 & 942 & 564 & 141 \\
\hline Arnavutköy & 1,173 & 584 & 150 & 889 & 677 & 253 \\
\hline Ataköy & 874 & 217 & 64 & 819 & 158 & 114 \\
\hline Avcilar & 158 & 55 & 127 & 133 & 26 & 140 \\
\hline Bahcelievler & 282 & 140 & 125 & 504 & 122 & 175 \\
\hline Bakirköy & 280 & 104 & 121 & 292 & 12 & 120 \\
\hline Balmumcu & 401 & 49 & 119 & 689 & 243 & 201 \\
\hline Baltalimani & 1,018 & 312 & 130 & 2,287 & 1,550 & 354 \\
\hline Bebek & 1,515 & 763 & 187 & 2,694 & 1,206 & 254 \\
\hline Besiktaş & 268 & 148 & 109 & 359 & 96 & 99 \\
\hline Cihangir & 221 & 130 & 97 & & & \\
\hline Emirgan & 692 & 427 & 164 & 946 & 703 & 329 \\
\hline Etiler & 629 & 335 & 143 & 650 & 191 & 169 \\
\hline Feriköy & 268 & 43 & 125 & 222 & 58 & 87 \\
\hline Findikzade & 176 & 67 & 83 & & & \\
\hline Florya & 645 & 299 & 195 & 587 & 109 & 271 \\
\hline Gayrettepe & 415 & 318 & 125 & 489 & 107 & 147 \\
\hline Gaziosmanpaşa & & & & 228 & 8 & 134 \\
\hline Halkali & 246 & 97 & 96 & 295 & 155 & 72 \\
\hline Kurtuluş & 234 & 62 & 119 & 283 & 138 & 112 \\
\hline 1. Levent & 597 & 563 & 152 & 923 & 364 & 217 \\
\hline
\end{tabular}

VOLUME 12, NUMBER 2, 2004 
Appendix (continued)

Characteristics of Housing Units in Neighborhoods: 1995 and 2000

\begin{tabular}{|c|c|c|c|c|c|c|}
\hline \multirow[b]{2}{*}{ Neighborhood } & \multicolumn{3}{|c|}{1995 Deflated at $\mathrm{CCl}$} & \multicolumn{3}{|l|}{2000} \\
\hline & Mean & $\begin{array}{l}\text { Std. Dev. } \\
\text { of Value }\end{array}$ & Size & Mean & $\begin{array}{l}\text { Std. Dev. } \\
\text { of Value }\end{array}$ & Size \\
\hline \multicolumn{7}{|c|}{ Panel A: Neighborhoods in the European Side (continued) } \\
\hline 4. Levent & 460 & 176 & 146 & 551 & 96 & 123 \\
\hline Maçka & 482 & 216 & 144 & 1,591 & 317 & 250 \\
\hline Maşlak & 295 & 205 & 155 & & & \\
\hline Mecidiyeköy & 260 & 71 & 120 & 284 & 129 & 117 \\
\hline Nişantaşi, Topağaci & 326 & 101 & 134 & 671 & 141 & 175 \\
\hline Ok Meydani & 235 & 65 & 90 & 136 & 45 & 125 \\
\hline Ortaköy & 519 & 236 & 192 & & & \\
\hline Şişli & 280 & 132 & 139 & 550 & 59 & 100 \\
\hline Tarabya & 799 & 267 & 199 & 604 & 181 & 194 \\
\hline Teşvikiye & 323 & 126 & 169 & 496 & 143 & 134 \\
\hline Ulus & 765 & 339 & 181 & 1,030 & 212 & 222 \\
\hline Yeniköy & 890 & 496 & 170 & 1,494 & 1,210 & 194 \\
\hline Yesilköy, Yeşilyurt & 734 & 206 & 160 & 648 & 130 & 265 \\
\hline Zeytinburnu & 123 & 27 & 125 & 173 & 121 & 82 \\
\hline \multicolumn{7}{|c|}{ Panel B: Neighborhoods in the Asian Side } \\
\hline Acibadem, Koşuyolu & 305 & 124 & 144 & 427 & 209 & 141 \\
\hline Ataşehir & 382 & 116 & 102 & 649 & 171 & 113 \\
\hline Bostanci & 292 & 126 & 144 & 265 & 78 & 138 \\
\hline Caddeboştan, Çiftehavuzlar & 486 & 225 & 157 & 521 & 213 & 166 \\
\hline Çengelköy & 135 & 30 & 141 & 524 & 409 & 242 \\
\hline Dragos & 601 & 241 & 215 & 583 & 386 & 248 \\
\hline Erenköy & 360 & 143 & 151 & 370 & 156 & 151 \\
\hline Fenerbahçe, Kalamiş, Dalyan & 504 & 226 & 154 & 448 & 225 & 153 \\
\hline Göztepe & 356 & 262 & 148 & 270 & 97 & 136 \\
\hline Içerenkoy & 182 & 22 & 126 & 202 & 46 & 133 \\
\hline Idealtepe & 218 & 79 & 151 & 202 & 77 & 138 \\
\hline Kadiköy & 201 & 84 & 108 & 198 & 33 & 90 \\
\hline Kandilli & 1,082 & 127 & 235 & 1,957 & 605 & 400 \\
\hline Kanlica & 1,377 & 782 & 140 & 1,761 & 792 & 430 \\
\hline Kartal & 165 & 60 & 133 & 160 & 58 & 134 \\
\hline Kazaşker, Tüccarbaşi & 265 & 67 & 130 & 233 & 54 & 137 \\
\hline Kozyataği & 272 & 71 & 137 & 284 & 93 & 134 \\
\hline Kurtköy, Yakacik, Tuzla & 88 & 5 & 100 & 140 & 46 & 134 \\
\hline Kuzguncuk & 967 & 755 & 164 & 948 & 207 & 294 \\
\hline K. Çamlica & 305 & 61 & 135 & 814 & 624 & 260 \\
\hline Maltepe & 207 & 96 & 148 & 170 & 39 & 142 \\
\hline Moda & 414 & 221 & 130 & 367 & 223 & 120 \\
\hline Pendik & 173 & 61 & 135 & 191 & 33 & 171 \\
\hline Şenesenevler & 252 & 68 & 133 & 281 & 54 & 152 \\
\hline Suadiye, Şaşkinbakkal & 407 & 218 & 156 & 446 & 217 & 155 \\
\hline Ümraniye & 120 & 31 & 111 & 216 & 104 & 128 \\
\hline Üsküdar & 192 & 60 & 109 & 176 & 42 & 126 \\
\hline Üsküdar-Coast & 584 & 348 & 180 & 771 & 446 & 199 \\
\hline
\end{tabular}

Notes: Mean and standard deviation of values (TL in million $\left./ \mathrm{m}^{2}\right)$ and mean size $\left(\mathrm{m}^{2}\right)$. 


\section{Endnotes}

1. Muth (1969) shows that these types of developments contribute to high residential prices.

2. The State Institute of Statistics provides the CCI for the whole country and for the four regions in Turkey. In the estimations, the CCI for the second region is used. Istanbul is included in this region.

3. The regression results did not change when house value appreciation rates in TL or US dollars are used. However, house values expressed in US dollars will underestimate house value appreciation rate because the average annual depreciation of TL against the US dollar was $62 \%$ for the period between 1995 and 2000. Furthermore, the average annual inflation rate was $65 \%$ for the same period. Therefore, the change in house values in terms of TL will result in underestimation of real house appreciation rate.

4. We would like to thank to the anonymous referee for pointing out this type of relationship.

\section{References}

Bernknopf, R. L., D. S. Brookshire and M. A. Thayer. Earthquake and Volcano Hazard Notices: An Economic Evaluation of Changes in Risk Perceptions. Journal of Environmental Economics and Management. 1990, 18, 35-49.

Brookshire, D. S. and W. D. Schulze. Methods Development for Valuing Hazards Information. University of Wyoming. 1980.

Brookshire, D. S., M. A. Thayer, J. Tschirhat and W. D. Schultze. A Test of the Expected Utility Model: Evidence from Earthquake Risks. Journal of Political Economy. 1985, 93, 36989.

Dokmeci, V. and L. Berkoz. Transformation of Istanbul from a Monocentric to a Polycentric City, European Planning Studies. 1994, 2:2, 193-205.

Dokmeci, V., H. Yurekli, H. Levent, G. Cagdas and L. Berkoz. Residential Preferences in Istanbul, Habitat International, 1996, 20:2, 241-251.

Dokmeci, V. and L. Berkoz. Residential-Location Preferences According to Demographic Characteristics in Istanbul. Landscape and Urban Planning. 2000, 48, 45-55.

Dokmeci, V. and G. Egdemir. Spatial Distribution of Residential Prices in Istanbul. Istanbul Technical University. Department of Urban and Regional Planning. Working Paper. 2001.

Egdemir, G. Istanbul Konut Fiyatlarinin Mekansal Analizi. Ph.D. Dissertation, Istanbul Technical University. 2001.

MacDonald, D. N., J. C. Murdoch and H. L. White. Hazards and Insurance in Housing. Land Economics. 1987, 63, 361-71.

Murdoch, J. C., H. Singh and M. Thayer. The Impact of Natural Hazards on Housing Values: The Loma Prieta Earthquake, Journal of the American Real Estate and Urban Economics Association, 1993, 21:2: 167-84.

Muth, R. Cities and Housing. Chicago, IL: University of Chicago Press. 1969.

Palm, R. Pre-Disaster Planning: The Response of Residential Real Estate Developers to Special Studies Zones. International Journal of Mass Emergencies and Disasters. 1987, 5, 95-102.

Palm, R. Natural Hazards: An Integrative Framework for Research and Planning. Baltimore, MD: Johns Hopkins University Press. 1990.

Tuker, B. E., J. G. Trumbull and S. J. Wyss. Issues in Urban Earthquake Risk. London: Kluwer. 1994.

Vandell, K. D. Market Factors Affecting Spatial Heterogeneity among Urban Neighborhoods. Housing Policy Debate. 1995, 6:1, 103-39.

Willis, K. G. and A. Asgary. The Impact of Earthquake Risk on Housing Markets: Evidence from Tehran Real Estate Agents. Journal of Housing Research. 1997, 8:1, 125-36.

VOLUME 12, NUMBER 2, 2004 